\title{
EXPERIMENTAL INVESTIGATIONS OF TEMPERATURE AND SUCTION EFFECTS ON COMPRESSIBILITY AND PRE-CONSOLIDATION PRESSURE OF A SANDY SILT
}

\author{
S. SAlager ${ }^{\mathrm{i})}$, B. FrançoIs ${ }^{\mathrm{i})}$, M. S. El Youssoufi ${ }^{\mathrm{ii}}$, L. LAloui ${ }^{\mathrm{i})}$ and C. SAIX ${ }^{\mathrm{ii})}$
}

\begin{abstract}
Research interest in the thermo-mechanical behaviour of unsaturated soils is growing as a result of an increasing number of geomechanical problems involving both thermal and unsaturated effects. In this framework, this paper addresses a unified thermo-mechanical experimental study of saturated and unsaturated states and, in so doing, contributes to the understanding of the non-isothermal mechanical behaviour of unsaturated soils. The present experimental program has been carried out on a sandy silt called "Sion silt" using two thermo-hydro-mechanical (THM) cells, one isotropic and one oedometric. The characteristics of these two cells are briefly presented, as well as the THM paths followed. The main results are presented and interpreted in the light of a suitable THM constitutive framework. The compressibility of the soil tested appears not to be affected by the temperature but decreases with a suction increase. As far as the apparent preconsolidation stress is concerned, the results show a decrease of the yield limit with increasing temperature, while a suction increase tends to enhance this limit. Finally, an analytical expression is proposed to describe the evolution of the apparent preconsolidation stress with respect to temperature and suction.
\end{abstract}

Key words: compressibility, isotropic tests, oedometric tests, preconsolidation pressure, thermo-mechanics, unsaturated soils (IGC: D5/D8)

\section{INTRODUCTION}

When a fine soil ${ }^{1}$ is simultaneously submitted to thermal, suction and mechanical loads, strong thermo-hydromechanical (THM) couplings occur. In particular, the mechanical behaviour of soils is attuned to unsaturation and thermal effects. In the field of environmental geomechanics, several relevant applications require an accurate knowledge of the thermo-mechanical behaviour of unsaturated soils (Vulliet et al., 2002). Among these applications, the feasibility study of nuclear waste disposal in deep geological formations is a major issue. In the first year following the closure of a high-level nuclear waste underground disposal, the soil in the near-field is subjected to complex mechanical stress, suction and temperature loadings with a great interdependence (Gens and Olivella, 2001). Moreover, high-voltage cable burials (Mitchell et al., 1982), petroleum extraction or geothermal structures using heat exchanger piles (Laloui et al., 2006a) may induce desaturation processes and thermal changes of the soil. As a result, the understanding and modelling of soil

\footnotetext{
A fine soil is assumed to be a soil in which the surface forces acting between particles are prevailing with respect to volumetric gravimetric forces.
}

surrounding such geostructures require an accurate thermo-hydro-mechanical framework based on comprehensive experimental test results.

On the one hand, there exist a great number of experimental studies concerning the hydro-mechanical behaviour of unsaturated soils under ambient temperature conditions. The main recent results in this field are given by Rampino et al. (2000), Cuisinier and Masrouri (2002), Lloret et al. (2003) and Geiser et al. (2006). On the other hand, a great number of experimental investigations of thermo-mechanical behaviour have also been carried out for the saturated state (Sultan et al., 2002; Jamin, 2003; Cekerevac and Laloui, 2004). The difficulties of these tests are mainly related to the control of undesirable temperature effects on various parts of the equipment.

In contrast, coupled effects of suction and temperature on soil mechanical behaviour have been the subject of few experimental studies. In these types of tests, the number of parameters which must be controlled increases considerably and numerous precautions must be taken to ensure accurate results. Among the few available results concerning THM experimental tests with simultaneous control of temperature, suction and stress state, one can note those under oedometric conditions, by Recordon (1993), Romero et al. (2003), Romero et al. (2005) and

i) Soil Mechanics Laboratory, Ecole Polytechnique Fédérale de Lausanne, Switzerland (lyesse.laloui@epfl.ch).

ii) Mechanical and Civil Engineering Laboratory, Université Montpellier 2, France.

The manuscript for this paper was received for review on May 18, 2007; approved on April 8, 2008.

Written discussions on this paper should be submitted before March 1, 2009 to the Japanese Geotechnical Society, 4-38-2, Sengoku, Bunkyoku, Tokyo 112-0011, Japan. Upon request the closing date may be extended one month. 
François et al. (2007), and those under triaxial and/or isotropic conditions, by Saix and Jouanna (1990), Saix (1991), Wiebe et al. (1998), Saix et al. (2000) and Tang (2005).

Throughout such THM experimental investigations, suction and temperature within the soil sample must be controlled, along with mechanical loading. Simultaneously, sample volume evolution and air or water exchange quantities must be measured. Concerning suction imposition, three main techniques can be used: the axis translation technique, the osmotic technique and the imposed relative humidity technique. Delage et al. (1998) exposed the principle of each technique with its advantages and drawbacks. Cekerevac et al. (2005) identified three main technique categories for applying temperature: i) heating by circulating fluid, ii) heating by internal heaters and iii) heating by lateral heaters. In contrast to the saturated case, for sample volume measurements under unsaturated conditions, both air and water exchanges contribute to the variation in soil specimen volume. Laloui et al. (2006b) summarized commonly used methods for measuring volume changes in unsaturated soil specimens.

Finally, in order to determine the soil water retention properties of the soil throughout the tests, exchanged volume of water has to be measured in addition to the volume variation of the sample. This requires specific baseline calibrations in order to subtract from the measured values the undesired thermal effect on the system.

This paper contributes to the field of thermo-mechanical behaviour of unsaturated soils under isotropic and oedometric conditions. In order to reduce the experimental time, the present experimental program has been carried out using two THM cells, one isotropic and one oedometric, on a sandy silt called "Sion silt". After presenting the specific material characteristics and the experimental devices, the THM paths and the main results are given. Finally, these results are interpreted in the light of THM constitutive framework. In particular, the effects of suction and temperature on the compressibility and the apparent preconsolidation stress of the soil are addressed.

In this experimental study, the two distinct categories of tests (isotropic and oedometric compression tests) require two different types of definitions for the controlled stresses and the measured yield limits. In order to clarify the terms used in this paper, definitions of stresses and yield limits are given in the APPENDIX.

\section{PREPARATION AND CHARACTERISTICS OF THE MATERIAL}

The soil examined in the research reported here is a sandy silt (USCS classification: CL-ML) from the region of Sion (Switzerland). This soil has already been the subject of many studies (Laloui et al., 1997; Geiser et al., 1998; Geiser et al., 2006). Its index properties are: $w_{\mathrm{L}}=$ $25.4 \%, I_{\mathrm{P}}=8.7 \%$. The grain-size distribution curve is presented in Fig. 1. The clayey fraction represents $8 \%$,

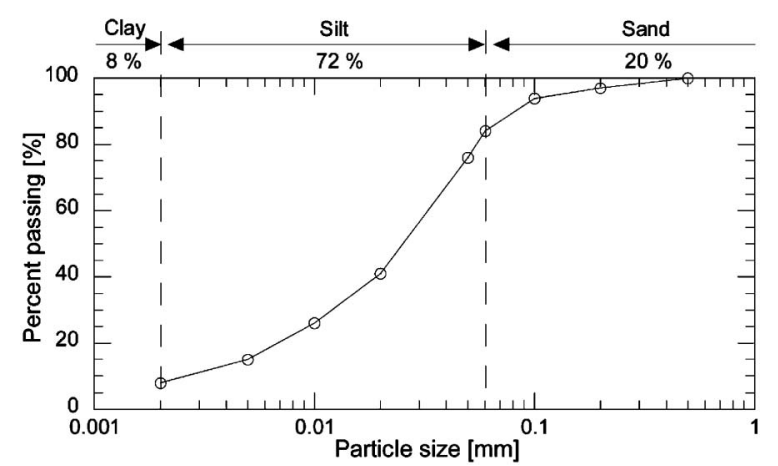

Fig. 1. Grain size distribution of "Sion silt"

the silty one about $72 \%$ and the sandy one about $20 \%$.

Special care was taken in the sample preparation to ensure the reproducibility of the initial state. The sample preparation procedure consisted of mixing a known mass of dry soil with de-aired and demineralised water to an initial water content $w=1.5 w_{\mathrm{L}}$ (i.e., $w=38 \%$ ). This water content value was assumed large enough to produce a slurry with no internal fabric. To remove the air bubbles trapped in the slurry, the soil was vibrated. The initial void ratio $e_{0}$ at the slurry state varied between 0.8 and 1 .

Such a slurry could be directly used in the oedometric cell, but its consistency was not well adapted to the isotropic cell. Therefore, the tests in isotropic conditions required getting a self-supporting soil specimen. To reach a satisfactory initial state for isotropic compression tests, a mechanical consolidation in oedometric conditions was first applied to the sample with a $47 \mathrm{kPa}$ vertical pressure for 10 minutes, and then with a $100 \mathrm{kPa}$ vertical pressure for 230 minutes. Secondly, a preliminary $50 \mathrm{kPa}$ suction was imposed. At the end of this fabrication process, a 0.72 mean void ratio and a $23.3 \%$ water content were obtained.

\section{EXPERIMENTAL DEVICES}

\section{THM Oedometer}

A new THM oedometric cell was developed which uses a cylindrical sample with a diameter of $80 \mathrm{~mm}$ and a height of $23 \mathrm{~mm}$. This cell enables standard oedometric compression tests by controlling temperature and suction in the sample and determining soil water retention characteristics under different mechanical and thermal states. Figure 2 displays the general scheme of this THM oedometric cell. The temperature $T$, the applied vertical total stress $\sigma_{\mathrm{v}}$, the pore air pressure $u_{\mathrm{a}}$ and the pore water pressure $u_{\mathrm{w}}$ can be controlled through four independent devices. The exchanged volume of water and the vertical displacement are simultaneously measured.

The heating device consists of a ring-shaped chamber that surrounds the soil sample and is filled with circulating water heated to the required temperature through a cryostat, DC10-K20 HAAKE. In order to reduce the ambient room temperature influence, the whole oedometer is located in an insulated box. 


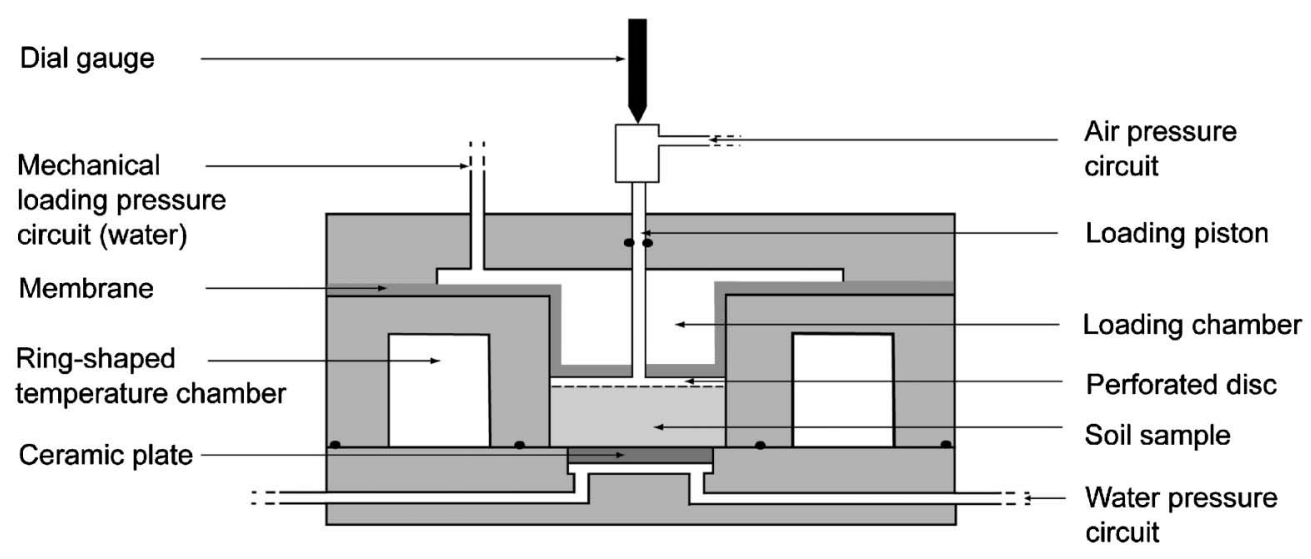

Fig. 2. General scheme of the THM oedometric cell

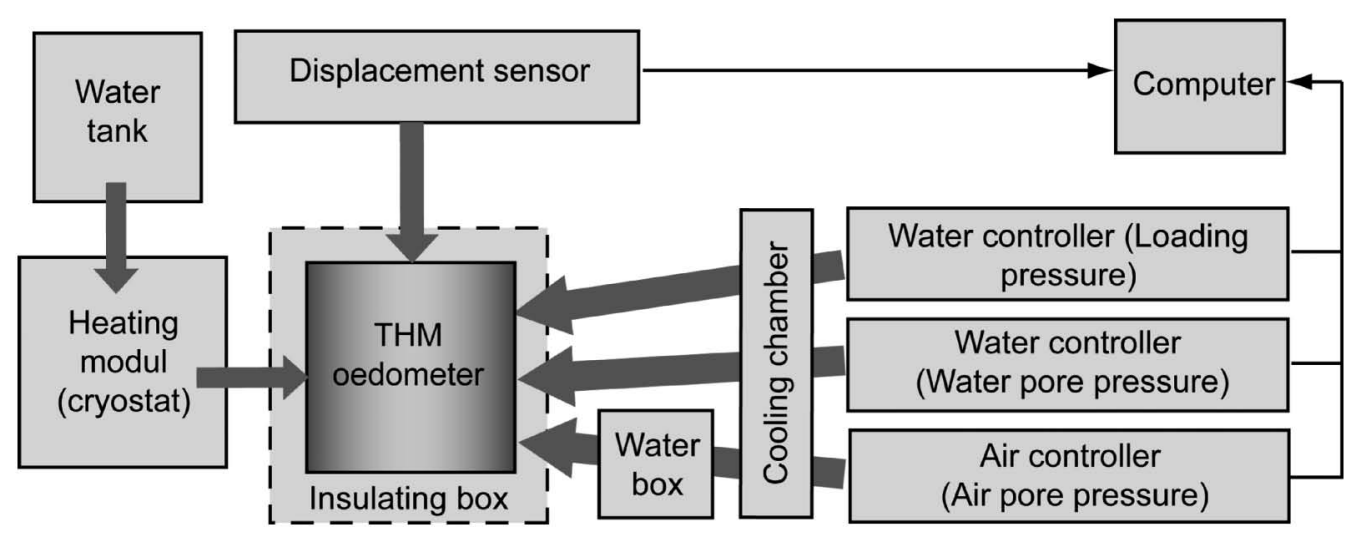

Fig. 3. Scheme of oedometric cell environment and the auxiliary devices

The vertical pressure is applied by a water controller in a loading chamber atop the sample. This pressure is transmitted to the sample via a water- and air-proof membrane made of a stretchable material (a polyurethane resin called monothane with a hardness A65). The suction (defined as the difference between the pore air and the pore water pressures) within the sample is imposed by the axis translation technique (air overpressure method). The pore air pressure is applied uniformly by an air controller via a loading piston ended by a perforated disc in contact with the top surface of the sample, while the pore water pressure is controlled through a $500 \mathrm{kPa}$ air-entry value ceramic plate beneath the sample. These three controllers enable application of and/or measurement of pressures and/or volume changes.

Finally, the vertical displacement is measured via a dial gauge fixed on an external frame and in contact with the loading piston. A computer continually stores the applied pressures, the measured volume exchanges and the vertical displacements while the temperature imposed by the cryostat is manually noted. All these auxiliary devices are schematically represented in Fig. 3.

In order to keep a constant temperature in the air and water controller chambers and thereby avoid volume measurement variations due to temperature, a cooling chamber with a water bath at $20^{\circ} \mathrm{C}$ is added along the air and water circuit before the controller cells. To avoid pore water evaporation at high temperature, a constant back-pressure of $80 \mathrm{kPa}$ is maintained by the water controller and a water box is connected to the air pressure line to humidify the dried air before connecting it to the sample (Fig. 3).

\section{THM Isotropic Cell}

In the same way, a THM isotropic cell has been developed to follow isotropic loading paths in unsaturated and non-isothermal conditions. The sample is cylindrical, with a diameter of $70 \mathrm{~mm}$ and a height of $15 \mathrm{~mm}$. Figure 4 shows a detailed description of the cell. The suction is applied by the axis translation technique similarly to the THM oedometric cell. A pneumatic circuit imposes a pore air pressure on top of the sample (up to $500 \mathrm{kPa}$ ). In order to limit the phase changes within the soil sample, the air is first saturated with vapour. A pressure sensor is used to measure the water pressure in the hydraulic circuit, and so, as a result of the continuity, in soil pores. The difference between these two pressures (pore air and pore water pressures) leads to the suction. The isotropic total stress $p$ is applied by pressurizing the air of the cylindrical cell. This pressure compresses the sample radially via the neoprene membrane and vertically via the loading plate. 


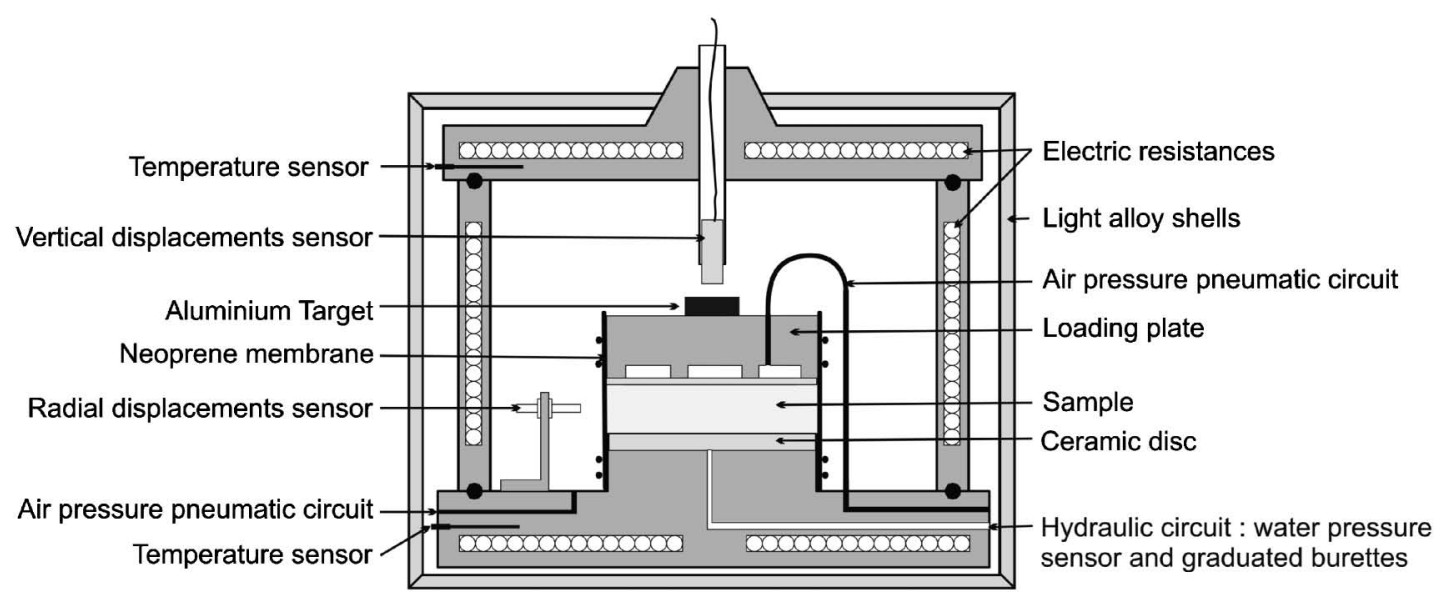

Fig. 4. General scheme of the THM isotropic cell

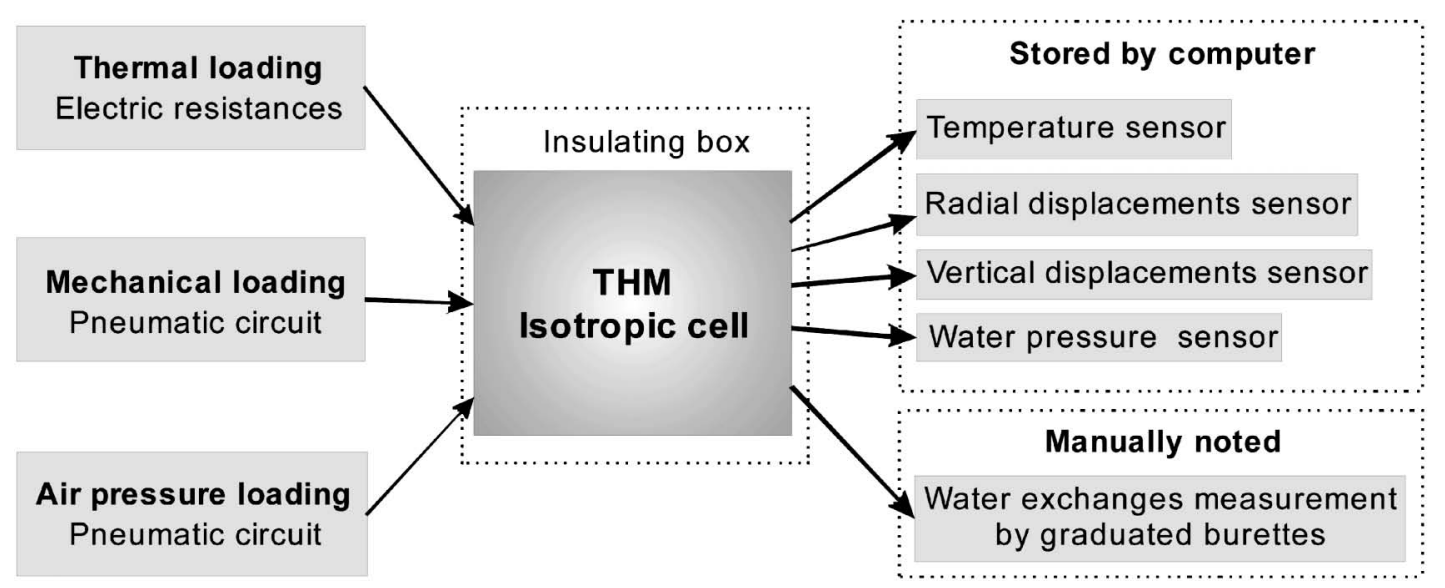

Fig. 5. Scheme of the isotropic cell environment and the auxiliary devices connected

Electrical resistances are inserted in the three massive parts of the cell. This device allows temperatures ranging from ambient to $80^{\circ} \mathrm{C}$ with an accuracy of $0.5^{\circ} \mathrm{C}$. The temperature is measured with two sensors located in the top and in the bottom of the cell. Two light alloy shells, each holding a 4-cm thick glass wool, serve as heat insulators.

The vertical and radial deformations are measured via two non-contact sensors that measure, by magnetic field, the distance between each of them and their aluminium target. The target of the vertical sensor is on the loading plate, while the one of the radial sensors is directly stuck to the sample membrane. From data obtained by these two non-contact sensors, the void ratio variation can be deduced.

The method used to measure the water content variation consists of measuring the water volumes coming in and going out of the soil sample through the ceramic disc. The measurements are made using graduated burettes accurate to $0.05 \mathrm{~cm}^{3}$. From these data and a reference water content (here, the final water content as measured by a weigh-in), the water content throughout the test can be determined. From the void ratio variation, the degree of saturation can also be calculated.
To summarise, as explained in Fig. 5, this apparatus applies isotropic total stress, suction and temperature loadings through three independent devices. Radial and vertical variations in the sample dimensions and exchanged volume of water can be measured. All these data are stored by a computer, except for the exchanged volume of water which is manually noted.

\section{Calibrations}

When performing THM experimental tests, the applied conditions (mechanical stresses, temperature, pore air and pore water pressure) and the measured data (exchanged volume of water and displacements) must be corrected in order to assess the real response of soil sample, deducting the undesired disturbances of measurements. To accomplish this careful calibration of the cells was made, including: i) the cells' deformability under thermal and mechanical loadings, ii) the delay between the thermal variation in the heating system and the real temperature change within the sample, iii) the influence of water thermal dilatation in tubings on the measurements of the exchanged volume of water, iv) the volume of water diffusing through the ceramic disk and v) in the case of oedometric cell, the effect of friction between the 
piston and cell walls for the vertical loading. The presentation of the quantitative assessment of these calibrations is beyond the scope of this paper. The interested readers may refer to Jamin (2003) and Ubals Picanyol (2006) for the calibration of isotropic and oedometric cells, respectively. In the following, only the calibration procedures are described.

i) The cell deformability under mechanical loadings was quantified using an undeformable steel disc in the sample chamber. Loading-unloading cycle was performed on this steel disc at two temperatures $\left(22^{\circ} \mathrm{C}\right.$ and $\left.80^{\circ} \mathrm{C}\right)$. Considering the disc undeformable, all the measured displacements are due to the cell structure deformation itself. Similarly, the cells' deformability under thermal loadings has been assessed by performing heatingcooling cycles on an INVAR sample placed in the sample chamber. INVAR having negligible thermal deformations, all the measured displacements are due to the cell structure deformation itself. Moreover, in the case of the oedometric cell, as proved by Romero (1999), the thermal dilatation of the oedometric ring remains insignificant with respect to a possible loss of oedometric conditions.

ii) The delay in the heating process has been assessed by placing thermo-couple in the middle of a soil sample and performing a heating-cooling cycle by a step of $10^{\circ} \mathrm{C}$ each 3 hours. This test has shown a delay of about 80 minutes, for the oedometric cell, and about 120 minutes, for the isotropic cell, to reach equilibrium between the heating system and the sample temperatures. Moreover, at equilibrium, there is no significant difference between the measured temperatures in the heating system and in the sample which proves the efficiency of the isolating system.

iii) To quantify the undesired volume change of the drainage system during temperature change, a stainless steel sample was placed in the sample chamber and a thermal cycle was performed. The measured exchanged volume of water during this calibration must be subtracted from the total volume variation measured during a test. In addition to this volume change in the drainage system, the pore water is also subjected to volume variation due to temperature. This volume variation also contributes to the total volume measurement of the water controller. This effect must be deducted in order to get the real volume of water expelled or soaked up by the soil sample.

iv) Even if High Air-Entry value ceramic Disk (HAED) is designed in order to avoid the passage of free air until a specific bubbling pressure, some air diffuses through the HAED, even at air pressures below the rated capacity (Romero, 1999; Padilla et al., 2006). Diffused air has a tendency to accumulate underneath the HAED resulting in an error in the specimen water volume measurement. This rate of air diffusion depends on the temperature level. This effect was calibrated during each test. When a consolidation process induced by any mechanical or suction loading is ended, the volume of expelled water presents a linear evolution with time. The slope of this evolution represents the flow rate of the air diffusion through the HAED.

v) In the case of the oedometer cell, the vertical pressure transferred by the membrane to the sample differs from the pressure applied by the controller in the loading chamber because of the friction occurring between this membrane and the oedometer wall. This difference has been quantified with respect to the applied vertical total stress during a mechanical loading and unloading by measuring the pressure of water placed instead of soil sample in the sample chamber. This has been done at two different temperatures $\left(22^{\circ} \mathrm{C}\right.$ and $\left.80^{\circ} \mathrm{C}\right)$.

\section{EXPERIMENTAL PROGRAM}

The experimental tests can be divided into two types:

- The first one assesses the temperature influence on the mechanical behaviour of the silt at a constant suction.

- The second one quantifies the suction influence on

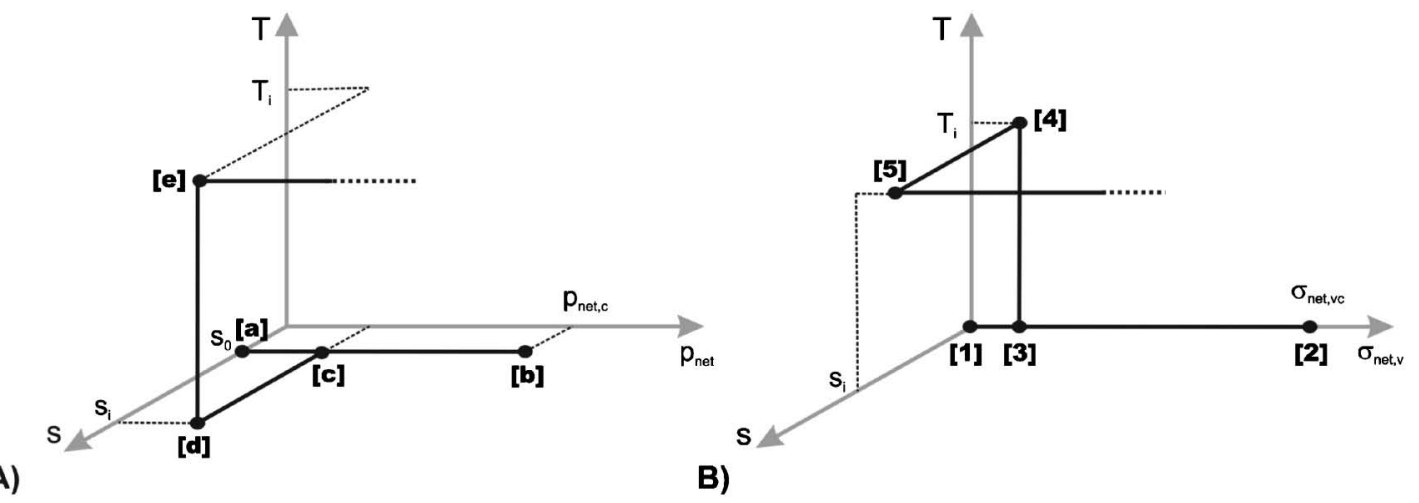

Fig. 6. The different steps of: A) isotropic tests and B) oedometric tests ( $T$ : temperature, $s$ : suction, $P_{\text {net }}$ : isotropic net stress, $\sigma_{\text {net, }}$ : vertical net stress) 
the mechanical behaviour of the silt at a constant temperature.

The first type of test is done by means of the isotropic cell, while the second type of test is done by means of the oedometric cell. Figure 6 presents the different steps involved in these tests; letters note the steps of the isotropic tests while numbers are used for the oedometric ones. In this figure, the origin of the temperature coordinate is the ambient temperature $\left(22^{\circ} \mathrm{C}\right)$.

The sample fabrication method is the same for the two test types, but their initial states differ: an unsaturated state for isotropic ones $\left(s_{0}=50 \mathrm{kPa}, 23.1<w<23.5 \%\right.$, $0.7<e<0.73)$ [a] and a saturated state for oedometric ones $(s=0 \mathrm{kPa}, w=38 \%, 0.8<e<1)$ [1]. For oedometric tests, one of the goals is to perform tests under saturated conditions. That involved starting the test with an initial state corresponding to a slurry. Consequently, the state of the sample is less well controlled and the initial value of void ratio is less reproducible. From these states, a mechanical loading [b,2]/unloading [c,3] cycle is applied to establish the preconsolidation stress for the sample $\left(p_{\mathrm{c}}^{\prime}=150 \mathrm{kPa}\right.$ for isotropic tests and $\sigma_{\mathrm{vc}}^{\prime}=100 \mathrm{kPa}$ for oedometric ones).

In the first type of test, this step is followed by drying until the required suction value $s_{\mathrm{i}}[\mathbf{d}]$ is reached. Then, the thermal loading is carried out through several steps long enough to avoid generation of excess pore water pressure (e.g., $10^{\circ} \mathrm{C}$ every 3 hours). This leads to the thermal consolidation curves of the silt for different suctions, until the required value $T_{\mathrm{i}}$ [e] is reached. The test is ended by a conventional mechanical consolidation which enables determination of the apparent preconsolidation pressure and the compressibility indices for the couples $\left(S_{\mathrm{i}}, T_{\mathrm{i}}\right)$. These isotropic tests were carried out for 3 suctions $(50$, 100 and $300 \mathrm{kPa})$ and 3 temperatures $\left(22^{\circ} \mathrm{C}, 45^{\circ} \mathrm{C}\right.$ and $68^{\circ} \mathrm{C}$ ), for a total of 9 tests.

For the second type of test, the thermal loading to the required value $T_{\mathrm{i}}$ [4] is done before the suction imposition $S_{\mathrm{i}}$ [5]. Then, the conventional mechanical consolidation is performed. These oedometric tests were carried out for 3 suction values $(0,100$ and $300 \mathrm{kPa})$ and 2 temperatures $\left(22^{\circ} \mathrm{C}\right.$ and $\left.80^{\circ} \mathrm{C}\right)$, with one duplication $\left(0 \mathrm{kPa}\right.$ and $\left.22^{\circ} \mathrm{C}\right)$, for a total of 7 tests.

All these tests (16 in total) are reported in Table 1. For each test the following parameters are prescribed: i) the established preconsolidation stress $\left(\sigma_{\mathrm{vc} 0}^{\prime}\right.$ or $\left.p_{\mathrm{c} 0}^{\prime}\right)$, ii) the temperature and the suction, and iii) the void ratio $\left(e_{0}\right)$ and the generalized effective stress $\left(\sigma_{\mathrm{v} 0}^{\prime}\right.$ or $\left.p_{0}^{\prime}\right)$ (see Eq. (1)) corresponding to the state of the specimen just before the mechanical consolidation.

For isotropic tests, the void ratio is measured at the end of the test by oil densitometry. From this information, the displacement sensor data allow calculation of the void ratio for each step of the test. In Table $1, e_{0}$ is not available for 3 tests. In fact, displacement data during the end of the final unloading could not be measured correctly. In these cases, the void ratio variations are known but not the void ratio.
Table 1. THM tests and the parameters defining the state, just before the final mechanical consolidation

\begin{tabular}{lcccccc}
\hline \multicolumn{1}{c}{ Tests } & $\begin{array}{c}\text { Mech. } \\
\text { path }\end{array}$ & $\begin{array}{c}\sigma_{\mathrm{vc} 0}^{\prime} \text { or } p_{\mathrm{c} 0}^{\prime} \\
(\mathrm{kPa})\end{array}$ & $\begin{array}{c}T \\
\left({ }^{\circ} \mathrm{C}\right)\end{array}$ & $\begin{array}{c}S \\
(\mathrm{kPa})\end{array}$ & $\begin{array}{c}e_{0} \\
(-)\end{array}$ & $\begin{array}{c}\sigma_{\mathrm{v} 0}^{\prime} \text { or } p_{0}^{\prime} \\
(\mathrm{kPa})\end{array}$ \\
\hline I-T22S50 & Iso & 198 & 22 & 50 & 0.70 & 98 \\
I-T45S50 & Iso & 198 & 45 & 50 & 0.69 & 98 \\
I-T68S50 & Iso & 198 & 68 & 50 & $\backslash$ & 98 \\
I-T22S100 & Iso & 220 & 22 & 100 & 0.69 & 120 \\
I-T45S100 & Iso & 220 & 45 & 100 & $\backslash$ & 120 \\
I-T68S100 & Iso & 220 & 68 & 100 & $\backslash$ & 120 \\
I-T22S300 & Iso & 261 & 22 & 300 & 0.67 & 171 \\
I-T45S300 & Iso & 261 & 45 & 300 & 0.65 & 171 \\
I-T68S300 & Iso & 261 & 68 & 300 & 0.66 & 171 \\
O-T22S0-1 & Oedo & 250 & 22 & 0 & 0.71 & 15 \\
O-T22S0-2 & Oedo & 134 & 22 & 0 & 0.85 & 1 \\
O-T80S0 & Oedo & 99 & 80 & 0 & 0.90 & 11 \\
O-T22S100 & Oedo & 100 & 22 & 100 & 0.66 & 71 \\
O-T80S100 & Oedo & 91 & 80 & 100 & 0.99 & 71 \\
O-T22S300 & Oedo & 100 & 22 & 300 & 0.74 & 121 \\
O-T80S300 & Oedo & 100 & 80 & 300 & 0.74 & 114 \\
\hline
\end{tabular}

\section{CONSTITUTIVE FRAMEWORK}

The generalized effective stress concept is a convenient way to continuously describe the triphasic nature of unsaturated soils (Jommi, 2000; Jardine et al., 2004; Nuth and Laloui, 2007a):

$$
\sigma_{\mathrm{ij}}^{\prime}=\left(\sigma_{\mathrm{ij}}-u_{\mathrm{a}} \delta_{\mathrm{ij}}\right)+S_{\mathrm{r}}\left(u_{\mathrm{a}}-u_{\mathrm{w}}\right) \delta_{\mathrm{ij}}
$$

where $\sigma_{\mathrm{ij}}$ is the total external stress, $u_{\mathrm{a}}$ and $u_{\mathrm{w}}$ are, respectively, the pore air and pore water pressures, $S_{\mathrm{r}}$ is the degree of saturation and $\delta_{\mathrm{ij}}$ is the Kroenecker's symbol. Equation (1) is based on the original Bishop's effective stress expression (Bishop, 1959) in which the effective stress parameter $\chi$ has been taken equal to the degree of saturation $S_{\mathrm{r}}$. Thereby, expressed as a function of the externally applied stresses and the internal fluid pressures, the effective stress converts a multi-phase porous medium to a mechanically equivalent, single-phase, single-stress state continuum (Laloui and Nuth, 2005). Consequently, the strain can be expressed with respect to this unique stress $\left(\sigma^{\prime}\right)$, the temperature $(T)$ and the internal variables $\left(\alpha_{\mathrm{k}}\right)$ :

$$
\varepsilon=\varepsilon\left(\sigma^{\prime}, T, \alpha_{\mathrm{k}}\right)
$$

Equation (1) requires the degree of saturation, $S_{\mathrm{r}}$, throughout the compression tests. The water retention properties of the "Sion silt" have been determined through two techniques. Firstly, independent of this experimental program, Péron et al. (2007) established, in desorption, the relationship between the degree of saturation and the suction (Fig. 7) with a pressure plate apparatus. The measurement was made at laboratory controlled temperature $\left(22^{\circ} \mathrm{C}\right)$ and for an initial void ratio of 0.75 , which is quite close to the void ratio achieved in the present study's compression tests. This curve shows an air-entry suction of $50 \mathrm{kPa}$. Secondly, the degree of saturation has also been extracted from the present isotropic and oedometric tests by monitoring the exchanged volume of water. These measurements required specific 


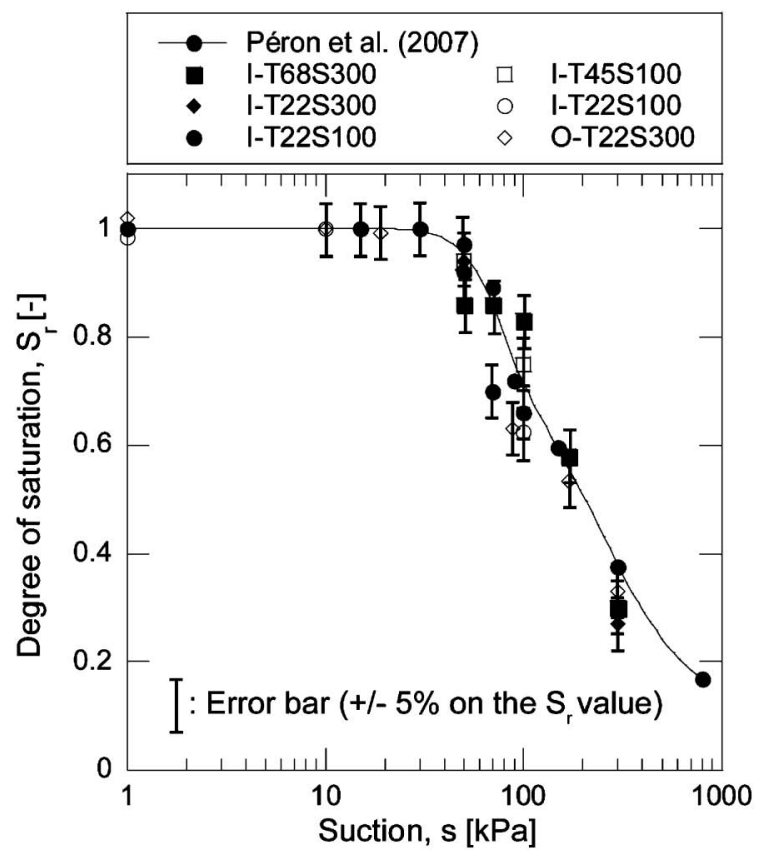

Fig. 7. Water retention curve determined in desorption of Sion silt; comparison between data obtained from oedometric and isotropic cells and from pressure plate apparatus

calibrations to consider several parasitic effects (the water thermal dilatation in tubes, the air diffusivity in the ceramic disc, the undesired air trapped in tubes, etc.). In spite of careful calibrations, it has been observed that the measurement of exchanged volume of water is not as accurate as the pressure plate apparatus test. Thus, with this method, an absolute error of $+/-5 \%$ on the degree of saturation value can be expected. Nevertheless, the degree of saturation versus suction relationships obtained from the oedometric and isotropic tests are also reported in Fig. 7 with the error bar of $+/-5 \%$. However, it has not been possible to obtain the evolution of $S_{\mathrm{r}}$ for each test due to occasional water leakage during some tests. In spite of these uncertainties, the results are quite close to the curve obtained by Péron et al. (2007).

Generally, it is shown that the soil water retention curve depends slightly on temperature (Salager et al., 2006; Romero et al., 2001) and also on dry density (an important effect for high degrees of saturation but slight for low degrees of saturation) (Salager et al., 2007). In this case, a predominant influence of temperature and void ratio on the obtained soil water retention curve has not been observed, at least for the encountered variations of temperature and dry density. These effects may exist but appear to be lower than the accuracy of the degree-ofsaturation measurement. Because of all these considerations, the degree of saturation will be determined through its univocal relationship with suction using the curve established by Péron et al. (2007). Therefore, the three imposed suctions of the experimental program $(50,100$ and $300 \mathrm{kPa}$ ) correspond to a particular degree of saturation $(0.96,0.70$ and 0.37 , respectively).

The choice of the generalized effective stress to inter- pret the experimental results may appear quite complex with respect to the two classical independent stress variables (net stress $\sigma_{\text {net, ij }}=\sigma_{\mathrm{ij}}-u_{\mathrm{a}} \delta_{\mathrm{ij}}$ and suction). Nevertheless, in terms of constitutive modelling, it is very convenient to use a unique stress variable coupled with the soil water retention curve (Nuth and Laloui, 2008).

Thus, all the results of the compression tests will be analysed in the light of the generalized effective stress and elasto-plasticity for which the elastic domain is limited by an isotropic yield limit (e.g., the apparent preconsolidation pressure). In the generalized effective stress framework, the normally consolidated slope, also called compression index $\lambda^{\prime}$, is given by:

$$
\lambda^{\prime}=\frac{\Delta e}{\ln \left(\frac{p_{1}^{\prime}}{p_{2}^{\prime}}\right)}=\frac{\Delta e}{\ln \left(\frac{p_{\text {net, },}+S_{\mathrm{r}} S}{p_{\text {net, } 2}+S_{\mathrm{r}} S}\right)}
$$

While in the net stress reference it is:

$$
\lambda=\frac{\Delta e}{\ln \left(\frac{p_{\text {net, } 1}}{p_{\text {net, }, 2}}\right)}
$$

where $\Delta e$ is the variation in void ratio induced by the mechanical loading between the mean net stresses $p_{\text {net, } 1}$ and $p_{\text {net, } 2}$ or the mean generalized effective stresses $p_{1}^{\prime}$ and $p_{2}^{\prime}$ on the normally consolidated line. Comparison of Eqs. (3) and (4) reveals that $\lambda^{\prime} \geq \lambda$. A similar comparison can be made for the swelling index $\left(\kappa^{\prime} \geq \kappa\right)$. Moreover, the evolution of the apparent preconsolidation stress with temperature and suction also depends on this stress variable choice.

\section{RESULTS}

The main goal of this experimental program is to study the mechanical response of soil under compression tests at different temperature and suction levels. However, the strain evolution of the soil along the preliminary temperature loading path has also been observed. Under isotropic conditions, at different unsaturated states $(s=$ $50 ; 100$ and $300 \mathrm{kPa}$, corresponding respectively to $S_{\mathrm{r}}=$ $0.96 ; 0.70 ; 0.37)$, the heating from $22^{\circ} \mathrm{C}$ to $68^{\circ} \mathrm{C}$ induces compaction (volumetric thermal strain $\varepsilon_{\mathrm{v}}^{\mathrm{T}} \approx 0.35 \%$ ) for the three suction levels. As shown in Fig. 8, the effect of suction does not seem to follow any trend, that can permit the assumption that thermal compaction is not affected by the suction level.

The experimental results of the oedometric and isotropic mechanical paths at different temperature and suction levels are reported in both net and generalized effective stress references in Figs. 9 to 12. It is of particular interest to display compression curves in terms of net stresses because they are the direct data monitored in the experiments, although the results will not be interpreted in this reference. Figure 9 reports the results in the oedometric cell and Fig. 10 in the isotropic one. By considering the soil water retention curve as exposed in the CONSTITUTIVE FRAMEWORK section and using Eq. (1), the results have also been expressed in the generalized 


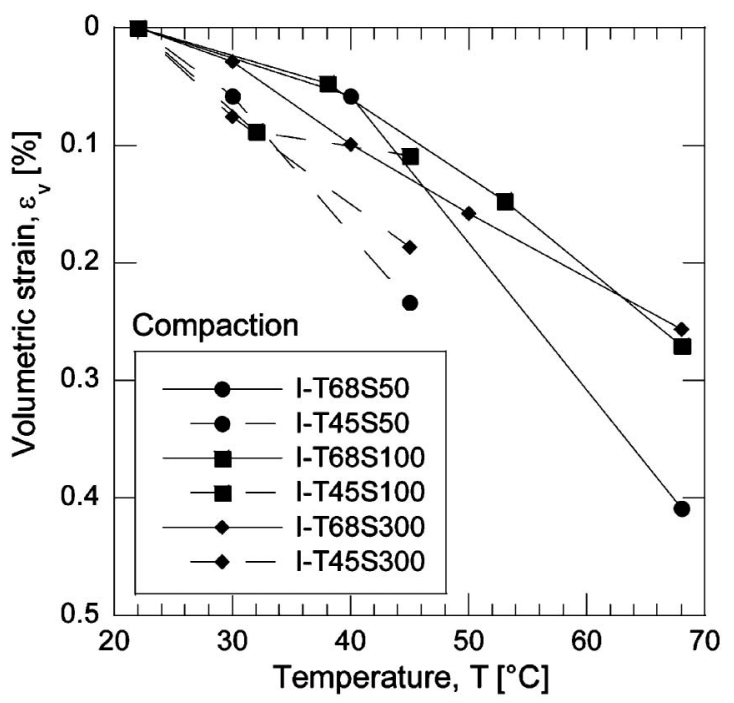

Fig. 8. Thermal paths at different suction levels effective stress reference. Figures 11 and 12 report the same results as Figs. 9 and 10, respectively, but in the generalized effective stress abscissa. Consequently, these curves are shifted forward by $\left(S_{\mathrm{r}} \times s\right)$ with respect to the results in the net stress reference. Because of the logarithmic scale of abscissa, this shift is not simply a translation of the curve to the right, but it also changes the shape and tends to flatten it.

After separate comparisons of the oedometric and isotropic curves in the generalized effective stress plan, they appear to exhibit normally consolidated lines that move towards higher stress levels with decreasing temperature and/or increasing suction. This will be analysed in the next section by quantifying the compressibility indices and the evolution of the apparent preconsolidation stress with respect to temperature and suction levels.

\section{INTERPRETATION OF THE RESULTS}

In this section, the effect of temperature and suction on the evolution of the compressibility indices and of the apparent preconsolidation stress $\left(\sigma_{\mathrm{vc}}^{\prime}\right.$ for the oedometric

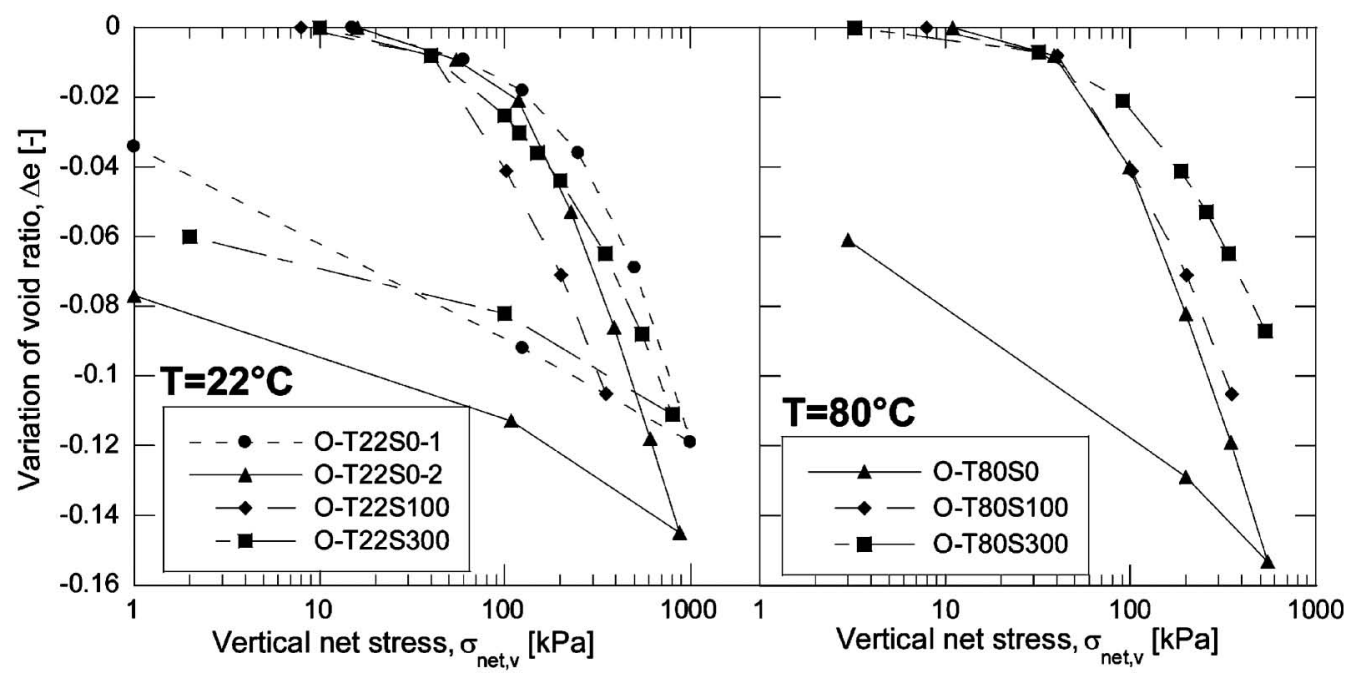

Fig. 9. Oedometric mechanical paths at different temperature and suction levels, reported in net stress

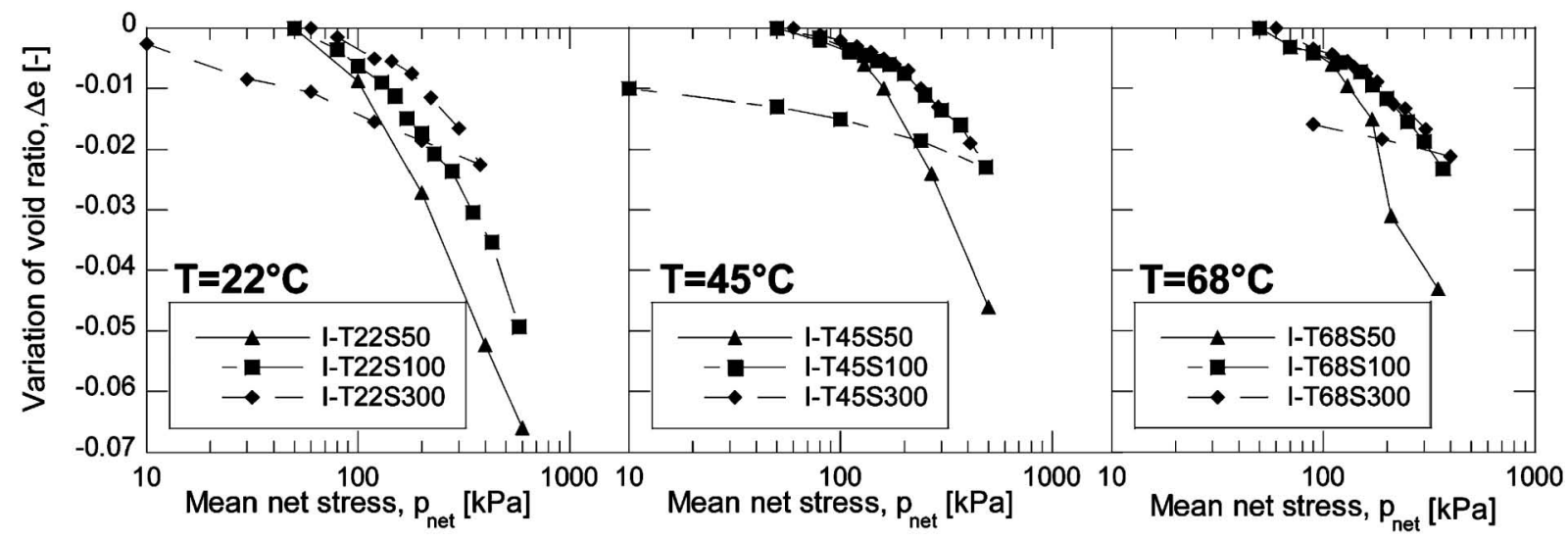

Fig. 10. Isotropic mechanical paths at different temperature and suction levels, reported in net stress 


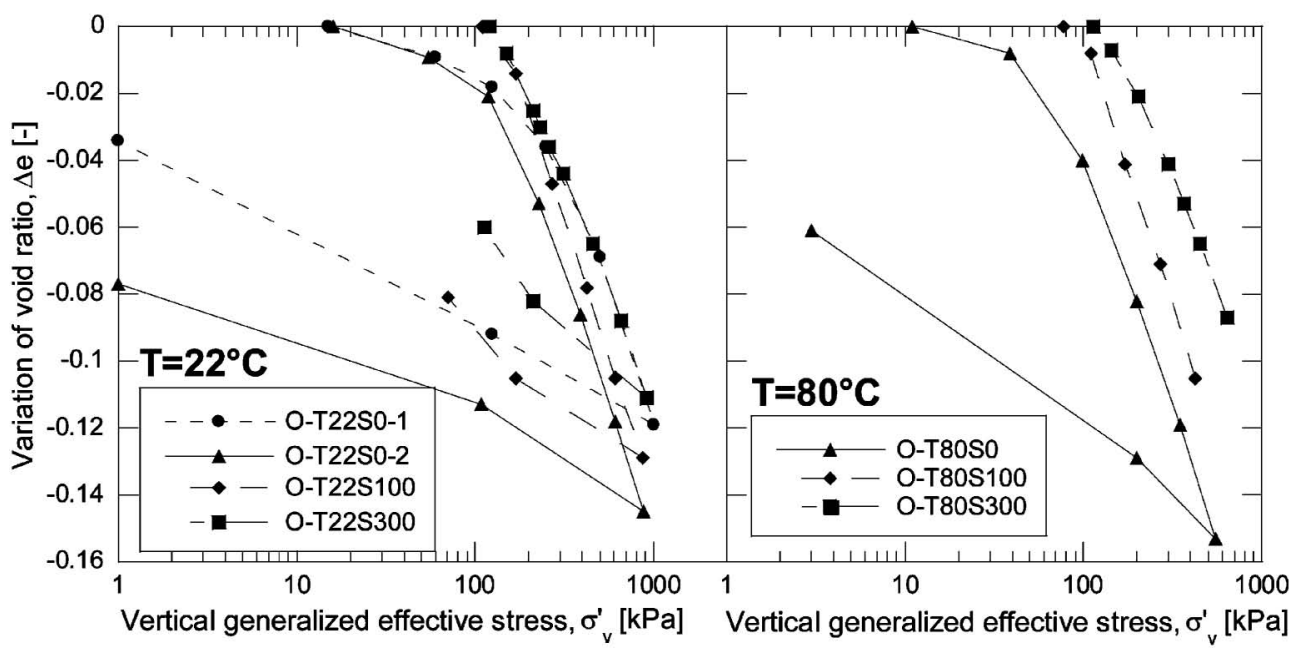

Fig. 11. Oedometric mechanical paths at different temperature and suction levels, reported in generalized effective stress

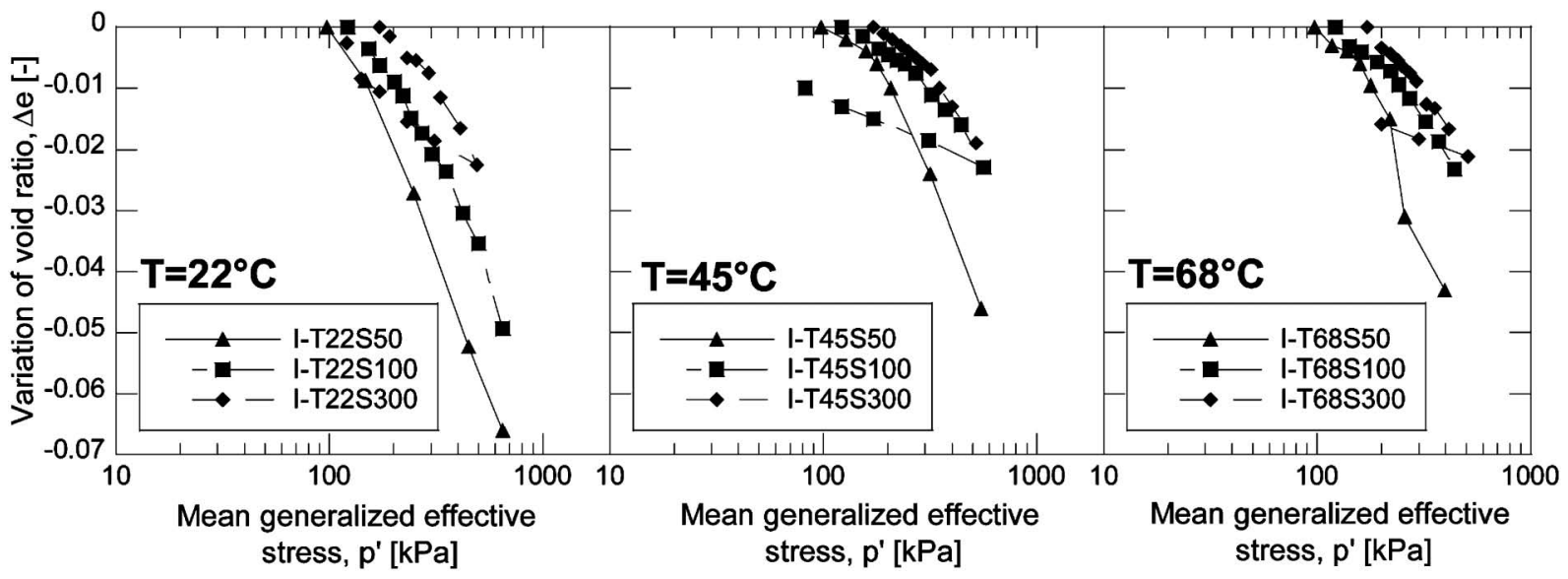

Fig. 12. Isotropic mechanical paths at different temperature and suction levels, reported in generalized effective stress

tests and $p_{\mathrm{c}}^{\prime}$ for the isotropic ones) will be assessed. For all the tests, these parameters have been determined using the following method: i) The unloading path being unavailable for all tests, $\kappa^{\prime}$ is determined from the elastic part of the loading path. Moreover, this value is confirmed, when possible, thanks to the unloading elastic path (between the first and last points of the unloading). In this case, it is noted as $\kappa_{\text {un }}^{\prime}$ (Table 2). In Fig. 13, only the unloading modulus is reported. ii) Because all the tests are not performed to the same final mechanical state, the compression index $\lambda^{\prime}$ is measured in a given generalized effective stress range, between 200 and 400 $\mathrm{kPa}$. iii) Using these two results, the apparent preconsolidation stress, $\sigma_{\mathrm{vc}}^{\prime}$ or $p_{\mathrm{c}}^{\prime}$, and its corresponding void ratio $e_{\mathrm{c}}$ are determined by calculating the intersection of the swelling line (line of slope $\kappa^{\prime}$ and passing through the initial points of mechanical loading) and the compression line (line of slope $\lambda^{\prime}$ and passing through the last points of mechanical loading).

In the $\left(p^{\prime}-q\right)$ plan (respectively, the mean generalized effective stress and the deviatoric stress), the yield surface of a soil has an elliptic shape which enlarges when the
Table 2. Apparent preconsolidation stress and compressibility indices obtained for the different THM tests

\begin{tabular}{lccccc}
\hline \multicolumn{1}{c}{ Tests } & $\begin{array}{c}\sigma_{\mathrm{vc}}^{\prime} \text { of } p_{\mathrm{c}}^{\prime} \\
(\mathrm{kPa})\end{array}$ & $\begin{array}{c}\sigma_{\mathrm{vc}}^{\prime} / \sigma_{\mathrm{vc} 0}^{\prime} \text { or } p_{\mathrm{c}}^{\prime} / p_{\mathrm{c} 0}^{\prime} \\
(-)\end{array}$ & $\begin{array}{c}\kappa^{\prime} \\
(-)\end{array}$ & $\begin{array}{c}\kappa_{\mathrm{un}}^{\prime} \\
(-)\end{array}$ & $\begin{array}{c}\lambda^{\prime} \\
(-)\end{array}$ \\
\hline I-T22S50 & 198 & 1.00 & 0.021 & - & 0.043 \\
I-T45S50 & 166 & 0.84 & 0.008 & - & 0.033 \\
I-T68S50 & 140 & 0.71 & 0.013 & - & 0.028 \\
I-T22S100 & 334 & 1.52 & 0.018 & - & 0.026 \\
I-T45S100 & 239 & 1.09 & 0.009 & 0.007 & 0.015 \\
I-T68S100 & 191 & 0.87 & 0.014 & - & 0.02 \\
I-T22S300 & 323 & 1.24 & 0.014 & 0.014 & 0.018 \\
I-T45S300 & 253 & 0.97 & 0.010 & - & 0.017 \\
I-T68S300 & 237 & 0.91 & 0.016 & 0.006 & 0.02 \\
O-T22S0-1 & 251 & 1 & 0.012 & 0.012 & 0.048 \\
O-T22S0-2 & 134 & 1 & 0.010 & 0.01 & 0.061 \\
O-T80S0 & 76 & 0.76 & 0.018 & 0.017 & 0.066 \\
O-T22S100 & 93 & 1.02 & 0.024 & 0.019 & 0.071 \\
O-T80S100 & 99 & 0.99 & 0.008 & 0.019 & 0.071 \\
O-T22S300 & 145 & 1.45 & 0.007 & - & 0.051 \\
O-T80S300 & 120 & 1.2 & 0.005 & 0.01 & 0.054 \\
\hline
\end{tabular}

void ratio decreases. Thus, the yielding surface is defined for a specific void ratio. To compare the initial precon- 


\section{Oedometric tests}

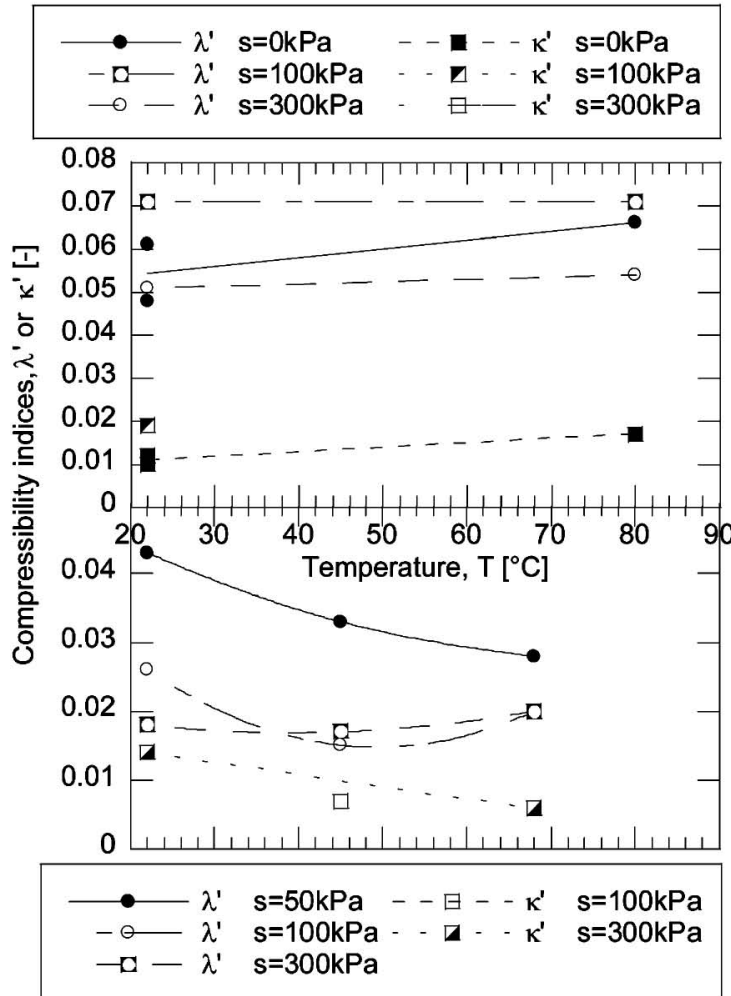

Isotropic tests

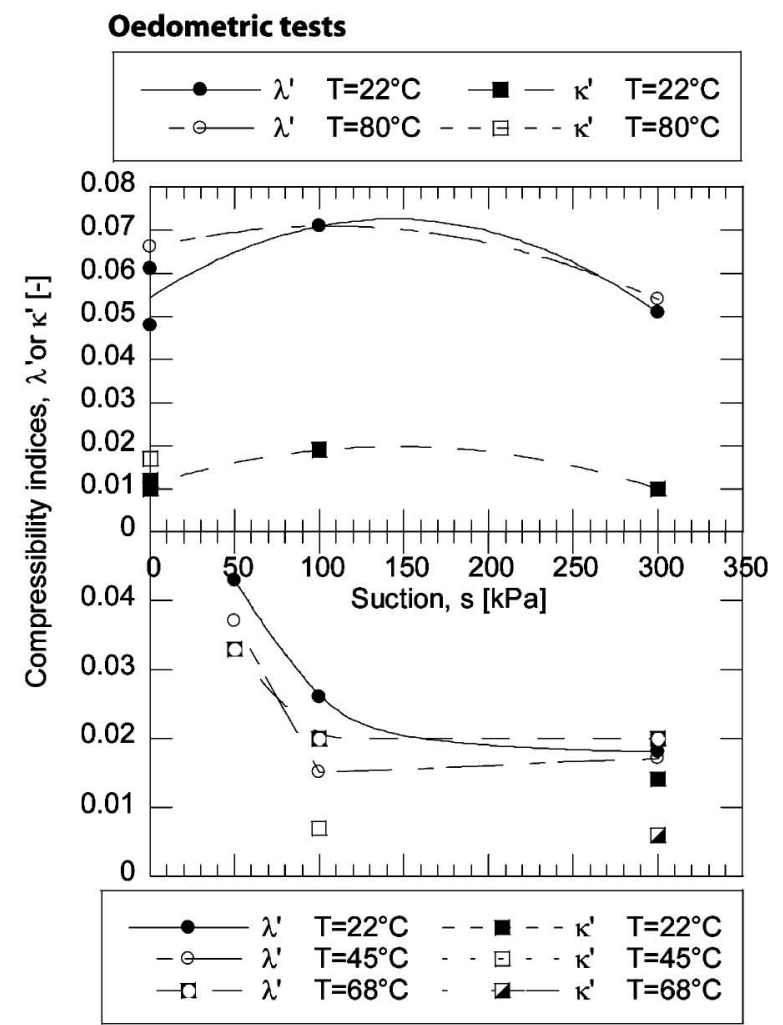

Isotropic tests

Fig. 13. Evolution of the compressibility indices with temperature and with suction

solidation stress applied to the soil, $\sigma_{\mathrm{c}}^{\mathrm{e}_{\mathrm{co}}}\left(T_{0}, S_{0}\right)$, corresponding to a void ratio $e_{\mathrm{c} 0}$, to the apparent preconsolidation stress determined after temperature and suction loadings, $\sigma_{\mathrm{c}}^{\mathrm{e}_{\mathrm{c}}}\left(T_{\mathrm{i}}, S_{\mathrm{i}}\right)$, corresponding to a void ratio $e_{\mathrm{c}}$, it is necessary to transpose these results to the equivalent void ratio. The correction, given by Atkinson and Bransby (1978), can be written as:

$$
\sigma_{\mathrm{c}}^{\mathrm{e}_{\mathrm{c}}}\left(T_{0}, s_{0}\right)=\sigma_{\mathrm{c}}^{\mathrm{e}_{\mathrm{c} 0}}\left(T_{0}, s_{0}\right) \exp \left(\frac{e_{\mathrm{c}}-e_{\mathrm{c} 0}}{\lambda^{\prime}}\right)
$$

Then, in order to estimate the temperature and suction effects on the apparent preconsolidation stress, the ratio $\sigma_{\mathrm{c}}^{\mathrm{e}_{\mathrm{c}}}\left(T_{\mathrm{i}}, S_{\mathrm{i}}\right) /\left(\sigma_{\mathrm{c}}^{\mathrm{e}_{\mathrm{c}}}\left(T_{0}, \sigma_{0}\right)\right.$ is used. To simplify the notation, this ratio, in term of generalized effective stress, is noted $\sigma_{\mathrm{vc}}^{\prime} / \sigma_{\mathrm{vc} 0}^{\prime}$ for oedometric tests and $p_{\mathrm{c}}^{\prime} / p_{\mathrm{c} 0}^{\prime}$ for isotropic ones.

Table 2 reports the $\kappa^{\prime}, \kappa_{\mathrm{un}}^{\prime}, \lambda^{\prime}$ and $\sigma_{\mathrm{vc}}^{\prime}$ or $p_{\mathrm{c}}^{\prime}$ parameters for all the THM compression tests.

Figure 13 reports the compressibility indices $\left(\kappa^{\prime}\right.$ and $\left.\lambda^{\prime}\right)$ of each compression test with respect to temperature (left graph) and suction (right graph). In general, this set of results does not exhibit a clear effect of temperature on the compressibility of the soils, at least for the range of temperatures considered in this experimental program. This negligible thermal effect on the compressibility indices is in agreement with other experimental evidence, such as the results of Cekerevac and Laloui (2004) on a saturated kaolin clay, or Tang (2005) on an unsaturated bentonite.
The data reported in Fig. 13 highlight that, globally, an increase of suction does induce a decrease in the compression and swelling indexes, at least for suction greater than the air-entry suction. This point is consistent with most of the literature on results observed at ambient temperature.

The mean compressibility indices are $\kappa^{\prime}=0.012$ and $\lambda^{\prime}=0.066$ for oedometric tests and $\kappa^{\prime}=0.014$ and $\lambda^{\prime}=$ 0.031 for isotropic ones. These values exhibit an isotropic compression index half that of the oedometric one. This last observation does not actually agree with the conventional soil mechanics hypothesis that the compression index is independent of the stress ratio (i.e., the ratio between the deviatoric and the mean generalized effective stress), provided that this ratio is kept constant all through the compression test (Biarez and Hicher, 1994). Nevertheless, previous experimental studies on the same materials have already exhibited such a difference between both mechanical compressibilities (Geiser, 1999).

Figure 14 underlines, respectively, the effects of temperature (left graph) and suction (right graph) on the apparent preconsolidation stress. The yield limit characterised by the apparent preconsolidation stress clearly depends on the temperature and suction levels applied to the soil. The yield surface tends to shrink when the temperature increases, while it expands when the suction increases.

In light of these experimental results, the apparent preconsolidation stress evolution with respect to tempera- 


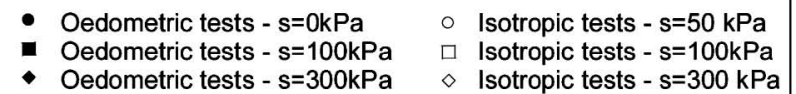

Oedometric tests - $s=300 \mathrm{kPa} \quad \diamond$ Isotropic tests - $s=300 \mathrm{kPa}$

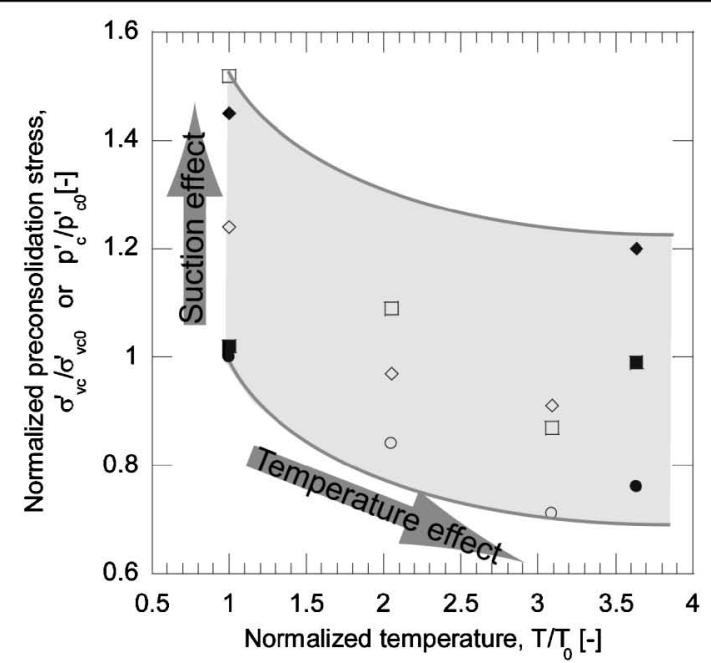

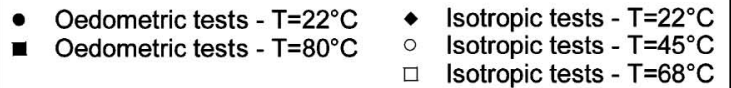

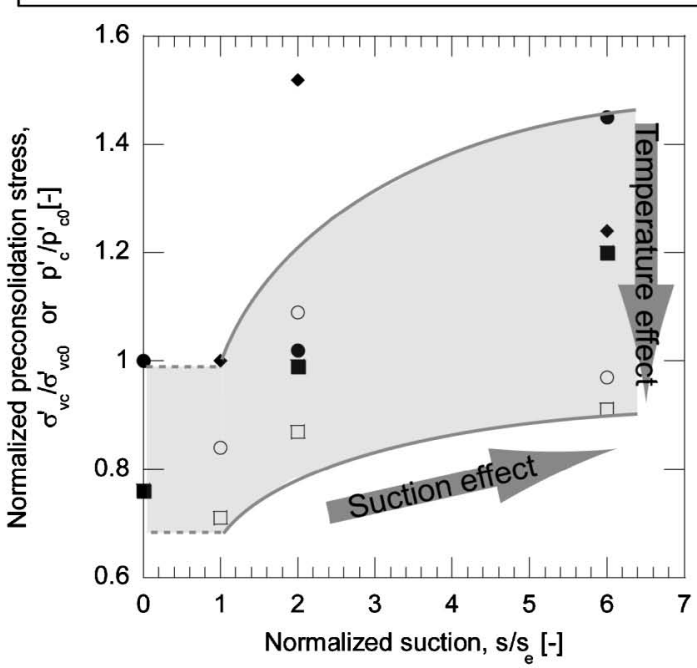

Fig. 14. Evolution of the apparent preconsolidation stress with temperature and with suction
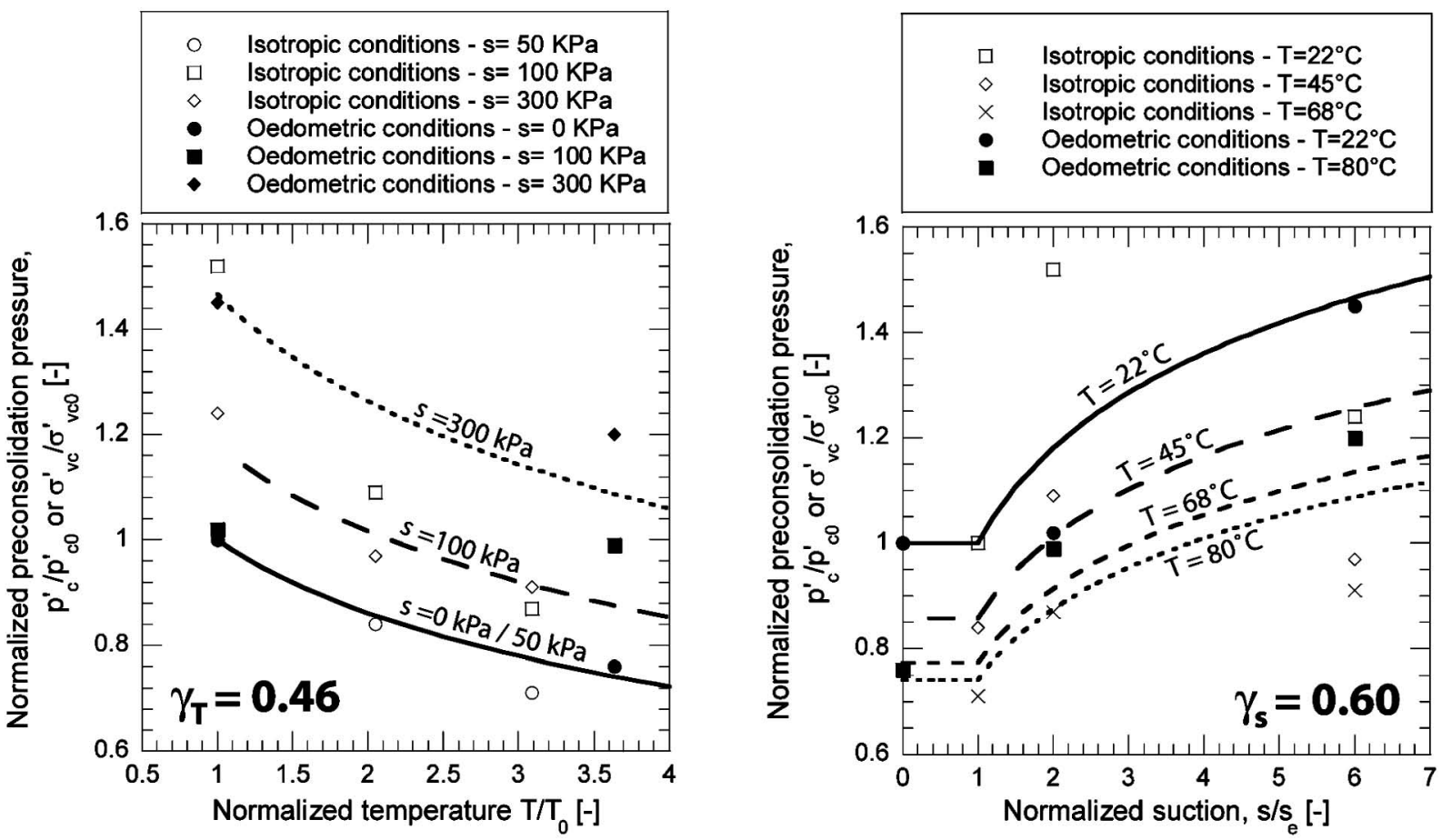

Fig. 15. Logarithmic trends of the evolution of the apparent preconsolidation stress with temperature and suction

ture and suction appears to be rapid for the low values of the two variables and becomes asymptotic for the high ones. Consequently, a logarithmic function might be suitable to model these two phenomena.

Laloui and Cekerevac (2003) proposed the following expression to represent the apparent preconsolidation stress decrease with heating for saturated conditions:

$$
\sigma_{\mathrm{c}}^{\prime}(T)=\sigma_{\mathrm{c} 0}^{\prime}\left(1-\gamma_{\mathrm{T}} \log \left(\frac{T}{T_{0}}\right)\right)
$$

perature $T_{0}, \sigma_{\mathrm{c}}^{\prime}(T)$ is the apparent preconsolidation stress at a given temperature $T$, and $\gamma_{\mathrm{T}}$ is a material parameter describing the evolution of $\sigma_{\mathrm{c}}^{\prime}$ with $T$.

The form of Eq. (6) is also suitable to predict the apparent preconsolidation stress increase with suction in isothermal conditions (François et al., 2007). In this expression, any suction lower than the air-entry value, $s_{\mathrm{e}}$, is assumed to have no influence on the apparent preconsolidation stress:

where $\sigma_{\mathrm{c} 0}^{\prime}$ is the preconsolidation stress at a reference tem- 


$$
\sigma_{\mathrm{c}}^{\prime}(s)= \begin{cases}\sigma_{\mathrm{c}}^{\prime}(s)=\sigma_{\mathrm{c} 0}^{\prime} & \text { if } s \leq s_{\mathrm{e}} \\ \sigma_{\mathrm{c}}^{\prime}(s)=\sigma_{\mathrm{c} 0}^{\prime}\left(1+\gamma_{\mathrm{s}} \log \left(\frac{s}{s_{\mathrm{e}}}\right)\right) & \text { if } s \geq s_{\mathrm{e}}\end{cases}
$$

where $\sigma_{\mathrm{c} 0}^{\prime}$ is the apparent preconsolidation stress at saturation, $\sigma_{c}^{\prime}(s)$ is the apparent preconsolidation stress at a given suction $s$, and $\gamma_{\mathrm{s}}$ is a material parameter describing the evolution of $\sigma_{\mathrm{c}}^{\prime}$ with $s$.

Equations (6) and (7) can be combined to express the evolution of the apparent preconsolidation stress with temperature and suction (François and Laloui, 2007):

$\sigma_{\mathrm{c}}^{\prime}(s)= \begin{cases}\sigma_{\mathrm{c}}^{\prime}(s)=\sigma_{\mathrm{c} 0}^{\prime}\left(1-\gamma_{\mathrm{T}} \log \left(\frac{T}{T_{0}}\right)\right) & \text { if } s \leq S_{\mathrm{e}} \\ \sigma_{\mathrm{c}}^{\prime}(s)=\sigma_{\mathrm{c} 0}^{\prime}\left(1+\gamma_{\mathrm{s}} \log \left(\frac{s}{S_{\mathrm{e}}}\right)-\gamma_{\mathrm{T}} \log \left(\frac{T}{T_{0}}\right)\right) & \text { if } s \geq S_{\mathrm{e}}\end{cases}$

For the ranges of suctions and temperatures considered in this work, the parameters $\gamma_{\mathrm{T}}$ and $\gamma_{\mathrm{s}}$ can be approximated to 0.46 and 0.60 , respectively. Figure 15 displays this proposed analytical evolution and compares it with the experimental results. In spite of the discrepancy in the obtained results, the trend of this logarithmic law meets satisfactory agreement with experiments. Nevertheless, it appears that $\gamma_{\mathrm{T}}$ depends on suction and $\gamma_{\mathrm{s}}$ on temperature but the development of a model describing these relationships must be supported by further experimental evidence. In the present case, parameter variations are not important, so the mean values of $\gamma_{\mathrm{s}}$ and $\gamma_{\mathrm{T}}$ yield satisfactory results.

\section{CONCLUSIONS}

A set of compression tests under different THM initial states have been carried out on a sandy silt using an isotropic and an oedometric cell. The main objective of this experimental program was to study the influence of combined temperature and suction on the compressibility indices and on the apparent preconsolidation stress. The results have been interpreted in the light of the generalized effective stress. This tends to show that temperature has no prevailing effect on compressibility indices. On the other hand, an increase of suction induces a decrease in the compression index. The apparent preconsolidation stress is strongly influenced by temperature and suction. A temperature increase tends to decrease the yield limit, while a suction increase enhances this limit, at least for suction higher than the air entry value. Finally, a quantitative logarithmic expression requiring two material parameters, one for the thermal evolution and another for the suction evolution, seems to describe these qualitative observations quite well.

\section{ACKNOWLEDGEMENTS}

This work was supported by the French Ministry of Foreign Affairs and the Swiss Academy of Engineering Sciences in the framework of an integrated action programme (PAI). The work of the Swiss group was also partly funded by the Swiss State Secretariat for Education and Research SER, Grant OFES C04.0021.

\section{REFERENCES}

1) Atkinson, J. H. and Bransby, P. L. (1978): The Mechanics of Soils-An Introduction to Critical State Soil Mechanics, McGrawHill London.

2) Biarez, J. and Hicher, P. (1994): Elementary Mechanics of Soil Behaviour. Saturated Remoulded Soils, Balkema.

3) Bishop, A. W. (1959): The principle of effective stress, Tecnisk Ukeblad, 39, 859-863.

4) Cekerevac, C. and Laloui, L. (2004): Experimental study of thermal effects on the mechanical behaviour of a clay, International Journal for Numerical and Analytical Methods in Geomechanics, 28, 209-228.

5) Cekerevac, C., Laloui, L. and Vulliet, L. (2005): A novel triaxial apparatus for thermo-mechanical testing of soils, Geotechnical Testing Journal, 28(2), 161-170.

6) Cuisinier, O. and Masrouri, F. (2005): Influence de sollicitations hydriques et mécaniques complexes sur le comportement d'un sol gonflant compacte, Canadian Geotechnical Journal, 42(3), 731741.

7) Delage, P., Howat, M. and Cui, Y. J. (1998): The relationship between suction and swelling properties in a heavily compacted unsaturated clay, Engineering Geology, 50(1-2), 31-48.

8) François, B. and Laloui, L. (2007): A stress strain framework for modelling the behaviour of unsaturated soils under non-isothermal conditions, Springer Proceedings in Physics 113, Theoretical and Numerical Unsaturated Soil Mechanics, 119-125.

9) François, B., Salager, S., El Youssoufi, M.S., Ubals Picanyol, D., Laloui, L. and Saix, C. (2007): Compression tests on a sandy silt at different suction and temperature levels, GeoDenver 2007 ASCE Geotechnical Special Publication, (157).

10) Geiser, F., Laloui, L. and Vulliet, L. (1998): Yielding of a remoulded sandy silt in saturated and unsaturated states, 2nd Int. Conf. on Unsaturated Soils, Beijing, China, 54-59.

11) Geiser, F. (1999): Comportement mécanique d'un limon non saturé: étude expérimentale et modélisation constitutive, PhD Thesis, EPFL, Lausanne.

12) Geiser, F., Laloui, L. and Vulliet, L. (2006): Elasto-plasticity of unsaturated soils: laboratory test results on a remoulded silt, Soils and Foundations, 46(5), 545-556.

13) Gens, A. and Olivella, S. (2001): Clay Barrier in radioactive waste disposal, Revue Française de Génie Civil, 5(6), 845-856.

14) Jamin, F. (2003): Contribution à l'étude du transport de matière et de la rhéologie dans les sols non saturés à différentes températures, PhD Thesis, Université Montpellier 2, France.

15) Jardine, R. J., Gens, A., Hight, D. W. and Coop, M. R. (2004): Developments in understanding soil behaviour, Advances in Geotechnical Engineering, The Skempton Conference, Thomas Telford, 103-206.

16) Jommi, C. (2000): Remarks on the constitutive modelling of unsaturated soils, Experimental Evidence and Theoretical Approaches in Unsaturated Soils, Trento, 139-153.

17) Laloui, L., Geiser, F., Vulliet, L., Li, X. L., Bolle, A. and Charlier, R. (1997): Characterization of the mechanical behaviour of an unsaturated sandy silt, 14th ICSMFE, Hamburg, 703-706.

18) Laloui, L. and Cekerevac, C. (2003): Thermo-plasticity of clays: An isotropic yield mechanism, Computers and Geotechnics, 30(8), 649-660.

19) Laloui, L. and Nuth, M. (2005): An introduction to the constitutive modelling of unsaturated soils, Revue Européenne de Génie Civil, 9(5-6), 651-669.

20) Laloui, L., Nuth, M. and Vulliet, L. (2006a): Experimental and numerical investigations of the behaviour of a heat exchanged pile, International Journal for Numerical and Analytical Methods in Geomechanics, 30, 763-781. 
21) Laloui, L., Péron, H., Geiser, F., Rifa'i, A. and Vulliet, L. (2006b): Advances in volume measurement in unsaturated triaxial tests, Soils and Foundations, 46(3), 341-349.

22) Lloret, A., Villar, M. V., Sànchez, M., Gens, A., Pintado, X. and Alonso, E. E. (2003): Mechanical behaviour of heavily compacted bentonite under high suction changes, Géotechnique, 53, 27-40.

23) Mitchell, J. K., McMillan, J. C., Green, S. L. and Sisson, R. C. (1982): Field testing of cable backfill systems, Underground Cable Thermal Backfill, Pergamon Press, New York, 19-33.

24) Nuth, M. and Laloui, L. (2007a): New insight into the unified hydro-mechanical constitutive modeling of unsaturated soils, Proc. 3rd Asian Conference on Unsaturated Soils 2007, 109-126.

25) Nuth, M. and Laloui, L. (2008): Effective stress concept in unsaturated soils: Clarification and validation of a unified framework, $I n-$ ternational Journal for Numerical and Analytical Methods in Geomechanics, DOI: 38, 771-801.

26) Padilla, J. M., Perera, Y. Y., Houston, W. N., Perez, N. and Fredlund, D. G. (2006): Quantification of air diffusion through high air-entry ceramic disks, Proc. 4th Int. Conf. on Unsaturated Soils, Arizona, USA, 1852-1863.

27) Péron, H., Hueckel, T. and Laloui, L. (2007): An improved volume measurement for determining soil water retention curves, Geotechnical Testing Journal, 30(1), 1-8.

28) Rampino, C., Mancuso, C. and Vinale, F. (2000): Experimental behaviour and modelling of an unsaturated compacted soil, Canadian Geotechnical Journal, 37, 748-763.

29) Recordon, E. (1993): Déformabilité des sols non saturés à diverses températures, Revue Française de Géotechnique, 65, 37-56.

30) Romero, E. (1999): Characterisation and thermo-mechanical behaviour of unsaturated Boom clay: An experimental study, $P h D$ Thesis, UPC, Barcelona.

31) Romero, E., Gens, A. and Lloret, A. (2001): Temperature effects on the hydraulic behaviour of an unsaturated clay, Geotechnical and Geological Engineering, 19, 311-332.

32) Romero, E., Gens, A. and Lloret, A. (2003): Suction effect on a compacted clay under non-isothermal conditions, Géotechnique, 53(1), 65-81.

33) Romero, E., Villar, M. V. and Lloret, A. (2005): Thermo-hydro- mechanical behaviour of two heavily overconsolidated clays, Engineering Geology, 81, 255-268.

34) Saix, C. and Jouanna, P. (1990): Appareil triaxial pour l'étude du comportement thermique de sols non saturés, Canadian Geotechnical Journal, 27, 119-128.

35) Saix, C. (1991): Consolidation thermique par chaleur d'un sol non saturé, Canadian Geotechnical Journal, 28, 42-50.

36) Saix, C., Devillers, P. and El Youssoufi, M. S. (2000): Eléments de couplage thermomécanique dans la consolidation de sols non saturés, Canadian Geotechnical Journal, 37, 308-317.

37) Salager, S., Jamin, F., El Youssoufi, M. S. and Saix, C. (2006): Influence de la température sur la courbe de rétention d'eau de milieux poreux, C. R. Mécanique, 334, 393-398.

38) Salager, S., El Youssoufi, M. S. and Saix, C. (2007): Experimental study of the water retention curve as a function of void ratio, GeoDenver 2007, ASCE Geotechnical Special Publication, (157).

39) Sultan, N., Delage, P. and Cui, Y. J. (2002): Temperature effects on the volume change behaviour of Boom clay, Engineering Geolo$g y$, 64(2), 135-145.

40) Tang, A. M. (2005): Effet de la température sur le comportement des barrières de confinement, $P h D$ Thesis, Ecole Nationale des Ponts et Chaussées, France.

41) Ubals Picanyol, D. (2006): Oedometric compression tests on unsaturated soils: Thermal and structural effects, Master Thesis, EPFL-UPC, Lausanne.

42) Vulliet, L., Laloui, L. and Schrefler, B. (2002): Environmental Geomechanics, EPFL Press, Lausanne.

43) Wiebe, B., Graham, J., Tang, X. and Dixon, D. (1998): Influence of pressure, saturation and temperature on the behaviour of unsaturated sand-bentonite, Canadian Geotechnical Journal, 35, 194-205.

\section{APPENDIX}

As far as oedometric compression tests are concerned, the stress is controlled according to vertical direction but the radial stress is unknown. On the contrary, in the

Table A1. Definition of the main used terms concerning the stresses and the yield limits (Bold symbols are used for tensors)

\begin{tabular}{|c|c|c|c|}
\hline Stress & Symbol & Definition & Type of test \\
\hline Total external stress & $\sigma$ or $\sigma_{\mathrm{ij}}$ & External stress applied to the sample. & - \\
\hline Net stress & $\sigma_{\text {net }}$ or $\sigma_{\text {net, ij }}$ & External stress minus air pressure. & - \\
\hline Generalized effective stress & $\sigma^{\prime}$ of $\sigma_{\mathrm{ij}}^{\prime}$ & Effective stress generalized to the case of unsaturated soils (see Eq. (1)). & - \\
\hline Mean net stress & $p_{\text {net }}$ & Average of the three principal net stresses. & Isotropic \\
\hline $\begin{array}{l}\text { Mean generalized effective } \\
\text { stress }\end{array}$ & $p^{\prime}$ & Average of the three principal generalized effective stresses. & Isotropic \\
\hline Vertical net stress & $\sigma_{\mathrm{net}, \mathrm{v}}$ & Vertical component of $\sigma_{\text {net }}$. & Oedometric \\
\hline $\begin{array}{l}\text { Vertical generalized } \\
\text { effective stress }\end{array}$ & $\sigma_{\mathrm{v}}^{\prime}$ & Vertical component of $\sigma^{\prime}$. & Oedometric \\
\hline Isotropic total stress & - & Term used in the experimental procedure for isotropic loading. & Isotropic \\
\hline Yield limit & Symbol & Definition & Type of test \\
\hline Preconsolidation pressure & $p_{c 0}^{\prime}$ & $\begin{array}{l}\text { The isotropic yield limit corresponding to the highest mean generalized } \\
\text { effective stress applied on the sample in its history. }\end{array}$ & Isotropic \\
\hline $\begin{array}{l}\text { Apparent preconsolidation } \\
\text { pressure }\end{array}$ & $p_{\mathrm{c}}^{\prime}$ & $\begin{array}{l}\text { The isotropic yield limit which may be affected by the temperature and the } \\
\text { suction of the soil. This variable depends not only the stress history of the } \\
\text { soil (as } p_{c 0}^{\prime} \text { ) but also the current temperature and suction level. }\end{array}$ & Isotropic \\
\hline $\begin{array}{l}\text { Vertical preconsolidation } \\
\text { stress }\end{array}$ & $\sigma_{\mathrm{vc} 0}^{\prime}$ & $\begin{array}{l}\text { The highest vertical generalized effective stress applied on the sample in its } \\
\text { history. }\end{array}$ & Oedometric \\
\hline $\begin{array}{l}\text { Apparent vertical } \\
\text { preconsolidation stress }\end{array}$ & $\sigma_{\mathrm{vc}}^{\prime}$ & $\begin{array}{l}\text { The yield limit of the soil determined on oedometric path. This variable } \\
\left.\text { depends not only on the stress history of the soil (as } \sigma_{c 0}^{\prime}\right) \text { but also on its } \\
\text { current temperature and suction. }\end{array}$ & Oedometric \\
\hline Preconsolidation stress & $\sigma_{\mathrm{c} 0}^{\prime}$ & $\begin{array}{l}\text { Generic term referring to the highest stress (mean generalized effective stress } \\
\text { for isotropic tests or vertical generalized effective stress for oedometric tests). }\end{array}$ & $\begin{array}{l}\text { Oedometric or } \\
\text { Isotropic }\end{array}$ \\
\hline $\begin{array}{l}\text { Apparent preconsolidation } \\
\text { stress }\end{array}$ & $\sigma_{\mathrm{c}}^{\prime}$ & $\begin{array}{l}\text { Generic term referring to the yield limit met along both oedometric or } \\
\text { isotropic compression path. This variable depends not only on the stress } \\
\left.\text { history of the soil (as } \sigma_{c 0}^{\prime}\right) \text { but also on the current temperature and suction } \\
\text { level. }\end{array}$ & $\begin{array}{l}\text { Oedometric or } \\
\text { Isotropic }\end{array}$ \\
\hline
\end{tabular}


isotropic compression tests, the same stress is applied according to the three principal directions. As a consequence, the results of oedometric tests focus on the vertical stresses, while the results of the isotropic compression tests are addressed through the mean stresses. Table A1 defines the main terms related to stresses and yield limits used in this study. 